\title{
A Funny Thing Happened When We Began to Write
}

\author{
Cecil Morris and Dana K. Haight
}

Every time we think of district-sponsored staff development, we think of the Rolling Stones' lyric: "You can't always get what you want." We don't seem to ever get what we want or what we need. Although some of the staff development programs we've attended have been good, all too often inservice training makes us passive and bored. Some outside expert comes in and develops us, while what we really want is the opportunity to develop ourselves.

Both of us are high-school English teachers interested in our own writing in addition to our attempts to teach writing. A year and a half ago, we began exchanging our writing, first with each other (very tentatively, we might add) and eventually with a writing group that included most of our department. We wrote poetry and prose, often following the models we shared with students in our classrooms. We responded to each other's work, sometimes in writing and sometimes in conversation, always attentively analyzing imagery and diction. In short, we practiced all those skills that we try to teach our students.

Quite by accident, we stumbled into an activity which we think is among the best staff development we've ever had; it is teacher-centered and teacher-driven. Our informal writing exchange made us active learners struggling with material that interested us deeply.

\section{The Process}

Before we began exchanging writing, we both had been involved in short-term writing groups, which we had found rewarding. At the time, neither of us was in a writing group, and we found it all too easy not to write without the deadline of a guaranteed audience. For some reason neither of us now remembers, we exchanged a pair of poems. We were so invigorated by the appreciative response we received that we wanted to continue our exchange.

When we did exchange writing, we always included a dated cover sheet that frequently began with an apology or excuse about the quality of the poem and then politely thanked the responder for taking the time to read it. (We were then and remain still very anxious about sharing our writing with a professional colleague.) Over the weekend, each responded in writing to the other's work. In the response, we frequently paraphrased the poem, commented on specific diction or imagery, reminisced about experiences or memories that the poem evoked, or referred to related published poems. Each response included specific praise, commendation, appreciation, and anticipation of the next installment.

Over time, we came to exchange a piece of writing every Friday; we operated under the credo that it was more important to exchange drafts regularly than to exchange masterpieces once every two or three years. The cover sheets and the responses evolved as well. The cover sheets came to include specific instructions for the reader to look at particular parts of the poem or to address focused questions about it. The responses gradually encompassed suggestions for revision. We pointed out words or phrases that jarred or detracted from the poem and often proposed alternates. Occasionally the author would submit two versions of the poem, and the responder would discuss their differing effects. 
As we grew as writers, we wanted a wider audience, so we invited our English department colleagues to join us in a monthly exchange of writing. We now collect writing from each participant, make copies, bind them into a small anthology, which we distribute a week before each meeting. At our gathering, authors read their pieces aloud, and the other people respond orally in the same way that we might respond in writing. The faculty writing group has met monthly since October of 1991.

\section{Observations}

Writing poetry made us hungry to read more poetry. We wanted to find models, get ideas, steal techniques-in short, be inspired. We found ourselves rummaging through the poetry sections in bookstores. We bought literary magazines, photocopied favorite contemporary poems, and passed them around. We even used some of these poems in our classrooms, augmenting the literature included in our textbooks.

Prior to our involvement in the faculty writing group, we rarely saw our English teaching colleagues. As with most teachers, we spent our days alone with our books and our students. We saw our colleagues mostly during monthly faculty and department meetings, where we shared little and lis-

Writing poetry made us hungry to
read more poetry. We wanted to find
models, get ideas, steal techniques-
in short, be inspired.

tened a lot. Of the fourteen people in our department, ten have participated in our writers' group where we eat, socialize, and talk about the nuts and bolts of our own literature. The writers' group proved so valuable that we frequently met for more than two hours after school on the last Friday of each month, and we continue to meet during the summer months. In fact, one of our school science teachers has asked to join the group, and we invite members of other departments to participate in this collegial enterprise.

Part of what makes a person professional is collegial interaction and consultation. Our writing group and the conversations we have there provide a foundation for professional dialogue which enriches our teaching and erodes the sense of isolation that sometimes overwhelms us. Our personal exchange of writing and responses, along with the writing group, has taught us a good deal about writing and the teaching of writing.

When we look back at the first responses we wrote to each other's poems, we find only praise and encouragement without any "constructive criticism" or suggestions for improvement. Looking back at those first poems, we readily see that there were things to be improved, but we intuitively knew that we weren't ready to give or receive criticism. Here is a sample comment Dana wrote in response to Cecil's poem about the women who frequent a public pool during adult swimming hours:

$1 / 23 / 91-$ I hope I am not soon described in the terms of the first stanza. The images are vivid: the moo-moos, the lumbering across the deck, the sagging, quivering flesh. I see the ravages of living here, but without harshness. I like the fact that the speaker is not judgmental. Aging happens.

Heaviness pervades the first stanza. Even the steam hangs, instead of rising. The women lumber, trapped in their skin that resembles pale and lusterless cement. Their flesh is sagging. They settle into the pool, like so much cheesecake on thighs.

Dana focuses on specific details that she finds effective. The response neither gushes nor praises falsely, yet it still encourages the writer by recognizing what was well done. A commentary like this seems the prime function of response: encouraging further writing.

In the following response, Cecil writes about experiences and memories evoked by Dana's poem about childhood trips to the creek:

\begin{abstract}
2/9/91-The images of the second verse, where the speaker and her father reach the creek, are more beautiful, more magical. The "spewing sand in raindrop patterns," the flat rocks that skip "across the water / in low, graceful arcs," and the heavy rocks making "guttural grunts," "making a fountain splash like fireworks" all suggest the beauty and the joy of creek-side play. Each of those images recalls to me parts of my own life. (I remember fishing with my father. He would sit patiently watching the poles, but I would gather rocks into two piles, skippers and splashers, and throw them into the water. I remember taking Kristi fishing and spending most of our time gathering and throwing rocks.) In this verse, the speaker's father teaches her "about stones," about something real and valuable, something hard and permanent.
\end{abstract}

Cecil affirms the accuracy of Dana's imagery by juxtaposing it with his own experiences. Responses like this connect writers and readers through similar memories, building trust and understanding. 
This trust becomes the context that will allow the writer to view criticism as constructive and positive rather than as defeating and negative. As well, the reader culls specific quotations from the poem the way literary critics write about published poetry so that the writer comes to view his or her work as important and worthy of attention and analysis. Furthermore, the reader's attention to the writer's diction encourages careful writing.

As time went on and we became more comfortable with each other as readers and more comfortable with ourselves as writers, we began to offer

\section{Responses connect writers and readers through similar memories, building trust and understanding.}

occasional suggestions and advice. In the following sample, Dana comments on Cecil's poem about a former student now arraigned for assault and battery:

$4 / 14 / 91-$ I wonder if you need the final line of the first stanza ("but I doubt his innocence"). I think your suspicions are evident in the second stanza, and I doubt the meaning would be less clear if you omitted that one line. The other images create a clear vision of a frightening and violent man, one our society has deemed suitable for law enforcement.

Dana offers a very specific suggestion for revision couched in tentative language and surrounded by praise. In fact, her suggestion affirms the praise as much as the praise justifies the suggestion. Here the criticism is truly "constructive"; it encourages while it instructs. Dana phrases the criticism more gently and carefully than we usually do in commenting on student papers.

In addition to teaching us about response, our writing opened new possibilities for understanding and interpreting the literature we taught. Previously we had thought about our class readings solely as subjects for analytical interpretation, but we came to view them as subjects for fictional and poetic interpretation as well. Several members of our department wrote poems about characters from class readings. The process of writing about characters from our readings made us see them and the readings in new ways. For example, in studying and teaching Julius Caesar, we usually focus on the conflicting loyalties that create the political drama, but in this poem Dana explores the personal drama underlying public action.
The Bitterness of Love

Daughter to Cato, wife to Lord Brutus,

I imagine you poised

holding perhaps a knife, glistening

freshly sharpened

close to your thigh

ready to slice the peachlike flesh

as a doctor might prepare to remove a tumor.

But your tumor is love,

your intent not to excise

but to tap and spill

to let the red drops bead and ooze along the cut

until they stream a path around the curve of your leg and fall to water the dark earth.

I wonder if you shivered

at the coldness of the blade,

the liquidity of your devotion.

Another woman might have pressed quickly

the knife into the skin,

looking away all the while.

I imagine you,

singly atoning for your father's grief

your husband's melancholy

slow and deliberate

as you apply pressure to the edge,

watching carefully,

pressing the skin together

to force

the blood inherited from your father,

offered for your lord.

When I tremble with the bitterness of love,

I think of Portia,

who swallowed fire to consume the scar on her thigh and everything else she had loved.

Thinking about Portia's point of view made us feel more as if we owned Julius Caesar; it came to have greater meaning in our own lives. We may never have been caught up in political intrigue, but we do understand the bittersweet nature of marriage. Cecil's response demonstrates that even the reader of the poem benefits from the new view into the play:

1/15/92-I've taught Julius Caesar at least half a dozen times, and I've read it even more often. I've spent hours thinking about Caesar and Brutus and Cassius and their motivations. I've turned their phrases over and over, considered their arguments and actions from various points of view and against various standards of evaluation. In all that reading and studying and teaching, I have never thought very much about Portia. I feel guilty about overlooking her now that I have read your poem. I like the way "The Bitterness of Love" introduces love into a play I have always thought to be mostly about honor and civic responsibility. I like how your poem suggests that civic duty and public honor (so dear to Brutus) 
rest upon something else, something more personal, more private.

Others in our group have written about characters from Death of a Salesman and Madame Bovary. We enjoyed writing and reading these poems so much that we brought the idea into our classrooms. We showed students our poems and asked them to think about a work of literature from a point of view different from the author's original. Their poems became part of their final exam for the semester.

\section{Reflection}

While stirring us from our comfortable and familiar roles as teachers of writing and literature, our experience as writers and responders has also made us face an unpleasant truth: we cannot give our students the kind of responses that they deserve, the kind that we have given each other. Genuine response requires lots of thought and time, sometimes as much as an hour per piece of writing, which we were able to give because we were exchanging only one poem a week. When we have to respond to 150 pieces of student writing every week or two, we can't possibly spend more than a few minutes on any one piece. Unfortunately, genuinely helpful response and efficient response are often incompatible. While we need to be efficient, to unshackle ourselves from hours and hours of grading, we cannot ignore the lasting satisfaction of receiving a response that tells us our work is worthy of prolonged and thoughtful attention.

In contrast to the responses we wrote each other, the responses we put on student papers are all too often like the ones that we have received from professional editors: "You capture moments

\section{Because of our experience as writers, we now seek to augment our terse written responses to student writing with carefully coached student responses.}

well, but the language doesn't feel charged, energetic enough." This comment mirrors fairly closely what we try to do in student response: balance positive and negative comments, justify the grade (or in this case, the rejection) with a vague judgment, and do both concisely. Still, it fails to motivate or to offer truly helpful suggestions for revision. Of course, that's not the editor's job, but it is ours.

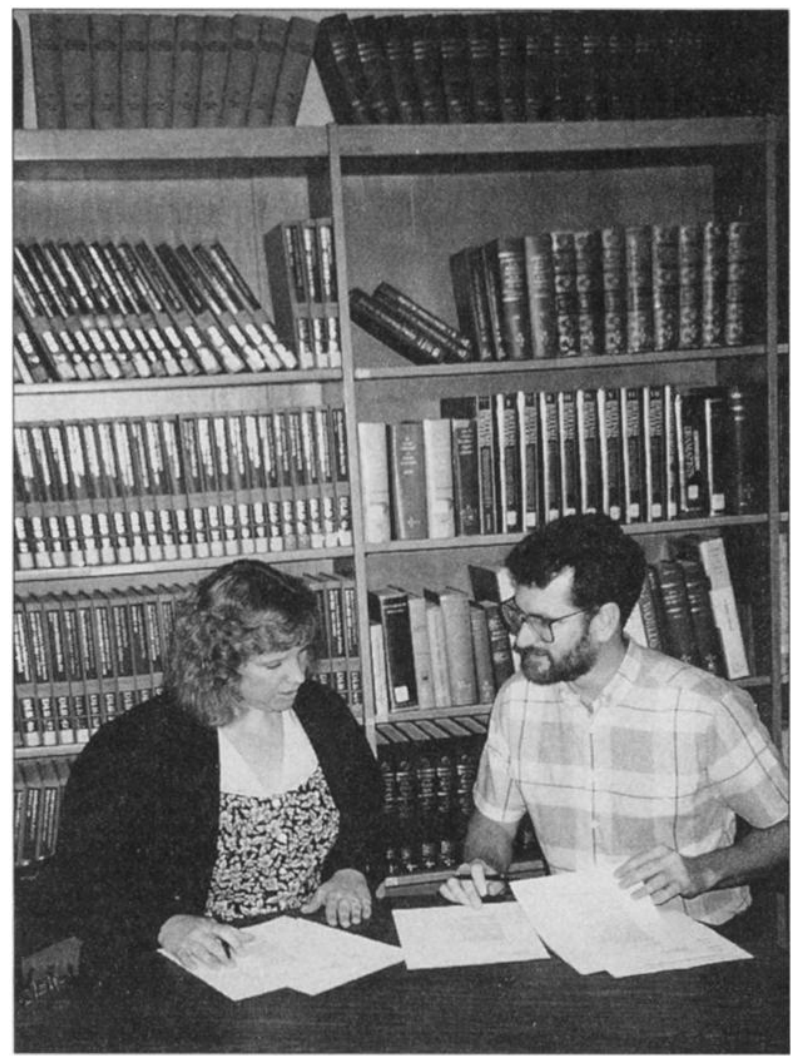

Since it is our job as teachers of writing to provide helpful and instructive response, we need to devise effective ways to do it. Our writing exchange has suggested what an ideal response might be. Because of our experience as writers, we now seek to augment our terse written responses to student writing with carefully coached student responses. We've begun using our own responses as models for training students how to pinpoint specific passages that are effective or perhaps ineffective and to offer direct and specific suggestions for revision. We also have taught them that the first job of response is to appreciate and to applaud what the writer has done well.

We had students turn in an anonymous piece of writing on a topic and in a genre of their own choice. Then we randomly redistributed those papers with the instructions that students write a careful and specific response to the author, a response modeled after the ones we had written for each other. Students enjoyed writing about their classmates' poems in the way they often had to write about "real" literature, perhaps because they knew they had an audience eager to read what they were writing. Students enjoyed reading the essays written about their poems, too; in fact, the day they 
received their peer responses was the quietest day in months.

After students got back their papers and their classmates' responses, we asked them to write about the experience. Their comments verified our impression that the long, thoughtful response benefitted writers:

2/27/92-In the comments I received from Janet, I noticed a different and narrow view on my [poem]. She looked at my examples of a musician, a dancer, and a writer as artists and figured that I meant beauty to be only conceived by artists. I actually hadn't considered that point of view. I appreciated her insight and it can enable me to revise my poem. Emily

2/27/92-Shayleen did a very good job discussing and finding the theme of my poem although she felt it had a universal message, but in reality it was personal. She felt that the idea of the poem was "we can escape the problems of the world for a few precious moments," which is the main idea of my poem, entitled clearly, "My Escape." I really enjoyed reading this response because I found which images worked the best and stood out. She commented on many of them, which helped me to discover their effectiveness. The only thing which surprised me was the idea that my poem had a deep universal message. It was purely on my idea of beauty and how the ocean [affects] me.

Melanie

Both students are highly interested in the response of their peers. The first mentions her plans to revise according to the suggestions offered her, and the second is pleasantly surprised by the breadth of meaning possible in her work.

We know that students trust and value their peers' opinions highly. If we can train them to provide detailed, analytical response to each other, then we are more likely to inspire thoughtful, substantive revision. We know, at least, that we were

\section{We sometimes feel like docents introducing great writing, but now we also feel like artists who create literature ourselves.}

inspired to revise and to continue writing when we received detailed, thoughtful comments from a reader we trusted.

\section{Conclusion}

Teaching makes it easy for us to isolate ourselves. When we enter our classrooms in the fall, taking up our various curricula like old tools, our busy-ness and our familiarity with our subject can deaden us.
We forget the joy of literature that made us choose to teach English. We also forget what our colleagues have to offer us. The ideal staff development should awaken us to the joy in our profession, help us recapture it, and unite us in meaningful discourse with our colleagues. We think that our writing exchange and our writing group have done that for us. We meet regularly with our fellow teachers to discuss the real issues of English-imagery and diction, meaning and style. We explore literature, finding new writers and writing to inspire us and to share with our students. We look at the literature already in our curriculum in new ways.

Over the past year and a half, we have seen our department become more cohesive; members of our department regularly write and discuss their writing with each other. We have become more intimately involved with literature. We sometimes feel like docents introducing great writing to an only occasionally appreciative audience, but now we also feel like artists who create literature ourselves. In the same way that aerobic exercise energizes the body for activities other than running or bicycling, our writing invigorates us, making us approach our teaching with greater enthusiasm and creativity. We have rediscovered the excitement of finding a new poem that says exactly the right thing, the kind of excitement we felt when we first came upon Matthew Arnold's "Dover Beach" or Robert Frost's "Death of the Hired Man." We find ourselves buying and reading books of poetry. Finally, and perhaps most important, we learned a good deal about responding to authors instead of just to literature.

It seems to us that this is what English teachers should do: read, write, think, talk, encourage, appreciate, and contribute to literature in all of its forms. We believe that our writing exchange and writing group actually address these issues and help members of our department develop into better readers, writers, and teachers.

When it comes to staff development, we can't always get what we want. But we can ensure that our own intellectual lives are vibrant, that we evaluate and revise our teaching regularly, and that we do both with our professional peers. That is staff development.

Roseville High School Roseville, California 95678 Menlo-Atherton High School Atherton, California 94027

December 1993 